\title{
RECOVERY OF DEGRADED PASTURE IN RONDÔNIA: MACRONUTRIENTS AND PRODUCTIVITY OF Brachiaria brizantha ${ }^{(1)}$
}

\author{
Norberto Cornejo Noronha ${ }^{(2)}$, Cristiano Alberto de Andrade ${ }^{(3)}$, Fernando \\ Célio Limonge $^{(4)}$, Carlos Clemente Cerri ${ }^{(5)}$, Carlos Eduardo Pellegrino \\ Cerri $^{(6)}$, Marisa de Cássia Piccolo ${ }^{(7)} \&$ Brigitte Josefine Feigl $^{(5)}$
}

\begin{abstract}
SUMMARY
Pasture is the main form of land use in Amazonia. Over time the pasture grass loses vigor and yields decrease, indicating a certain degree of degeneration. The main causes of degradation are lack of pasture maintenance and subsequent weed infestation, the choice of regionally unsuitable forage species and excessive grazing. The main purpose of this study was to evaluate the impact of different recovery managements on soil chemical properties and grass yield of a degraded pasture in Rondônia. For this purpose, an experiment was installed in October 2001, consisting of five treatments: $\mathrm{C}=$ control; $\mathrm{HA}=$ harrowing $+\mathrm{NPK}+$ micronutrients; $\mathrm{HE}=$ Herbicide + NK + micronutrients; $\mathrm{R}=$ No-tillage rice $+\mathrm{NPK}+$ micronutrients; and $\mathrm{S}=$ No-tillage soybean $+\mathrm{PK}+$ micronutrients. The following $\mathrm{N}, \mathrm{P}$ and $\mathrm{K}$ sources were used: ammonium sulfate for $\mathrm{N}$, calcined phosphate for $\mathrm{P}$ and potassium chloride for $\mathrm{K}$. The experiment was arranged in a randomized block design with four replications. The shoot dry matter yield of the grass was analyzed as of the
\end{abstract}

(1) Part of the doctoral thesis of first author submitted to the Postgraduate Program of the Center for Nuclear Energy in Agriculture, University of São Paulo - CENA/USP. Support: FAPESP/CNPq. Received for publication in October 2009 and approved in July 2010.

${ }^{(2)}$ Professor at the Institute of Agricultural Sciences, Rural Federal University of Amazon - ICA/UFRA. Avenida Tancredo Neves, 2501, PO Box 917, CEP 66077-530 Belém (PA) Brazil. E-mail: norberto.noronha@ufra.edu.br

(3) Researcher at the Centre for Soil and Environmental Resources, Agronomic Institute of Campinas - IAC. Av. Doutor Theodureto de Almeida Camargo 1500, Jardim Nossa Senhora Auxiliadora, CEP 13075-630 Campinas (SP) Brazil. E-mail: andrade@iac.sp.gov.br

(4) Agronomist, CPS manager. Caterpillar Brazil Ltda. Rod Luiz de Queiroz 157 km, s/n., CEP 13400-000 Piracicaba (SP). E-mail: flimonge@yahoo.com.br

(5) Professor at the Environmental Biogeochemistry Laboratory, CENA/USP. Av. Centenário 303. CEP 13400-970 Piracicaba (SP) Brazil. E-mail: cerri@cena.usp.br

(6) Professor at the Department of Soils and Plant Nutrition, Superior School of Agriculture "Luiz de Queiroz". ESALQ Av. Pádua Dias 11, PO Box 9, CEP 13418-900 Piracicaba (SP) Brazil. E-mail: cepcerri@esalq.usp.br

(7) Professor at the Nutrient Cycling Laboratory, University of São Paulo - CENA/USP. Av. Centenário 303, CEP 13400-970 Piracicaba (SP) Brazil. E-mail: marisa.piccolo@pq.cnpq.br 
$35^{\text {th }}$ month of experimentation, in a dry and a rainy period. Phosphorus fertilization resulted in significant increases in $\mathrm{Ca}^{2+}$ and $\mathrm{Mg}^{2+}$ and increasing trend of $\mathrm{P}$ in the topsoil in the initial months of the experiment in treatments HA and S and increases in $\mathrm{Ca}^{2+}$ and $\mathrm{P}$ (trend) in the treatment $\mathrm{R}$. The cumulative production of Brachiaria brizantha, from Sep/2004 to Mar/2005, was 30,025, 28,267 and 27,735 kg ha-1 shoot dry matter in the treatments $H A, R$ and $S$, respectively. These values differed significantly from treatments $\mathrm{C}$ and $\mathrm{HE}$, with 17,040 and $17,057 \mathrm{~kg} \mathrm{ha}^{-1}$, respectively. It was concluded that phosphorus fertilization associated to pasture reform was effective to raise the dry matter yield of Brachiaria brizantha. Rice or soybean under no-tillage is recommended as a practice of pasture recovery, due to the residual effect of fertilization.

Index terms: pasture rehabilitation, soil, fertilization, phosphorus, phosphate.

\author{
RESUMO: RECUPERAÇÃO DE PASTAGEM DEGRADADA EMRONDÔNIA: \\ MACRONUTRIENTES E PRODUTIVIDADE DA Brachiaria \\ brizantha
}

\begin{abstract}
As pastagens consistem no principal uso da terra na Amazônia. Com o tempo de utilização do pasto, a graminea perde o vigor e reduz a produtividade, caracterizando algum estado de degradação. Entre as principais causas de degradação estão a falta de manutenção do pasto e consequente infestação de plantas invasoras, a escolha de espécies forrageiras inadequadas à região e o pastejo excessivo. O objetivo principal desta pesquisa foi avaliar o impacto de diferentes manejos de recuperação sobre os atributos químicos do solo e a produtividade da graminea numa pastagem degradada em Rondônia. Para atingir esse objetivo, foi instalado, em outubro de 2001, um experimento composto de 5 tratamentos: $T$ = testemunha (controle); $G=$ gradagem $+N P K+$ micronutrientes; $H=$ herbicida $+N K+$ micronutrientes; $A=$ plantio direto de arroz $+N P K+$ micronutrientes; $e S=$ Plantio direto de soja $+P K+$ micronutrientes. As seguintes fontes de $N, P$ e K foram utilizadas: sulfato de amônio para $N$, termofosfato para $o$ P e cloreto de potássio para o K. O delineamento experimental foi em blocos ao acaso, com quatro repetições. A produção de matéria seca da parte área da gramínea foi analisada a partir do trigésimo quinto mês de experimentação, englobando um período seco e outro úmido. A adubação fosfatada propiciou incrementos significativos de $\mathrm{Ca}^{2+}$ e $\mathrm{Mg}^{2+}$ e tendência de aumento de P na camada superficial do solo nos primeiros meses de condução do experimento nos tratamentos $G$ e S e incrementos de $\mathrm{Ca}^{2+}$ e P (tendência) no tratamento A. A produtividade acumulada de Brachiaria brizantha, obtida entre os meses de set/2004 e mar/2005, foi de 30.025, 28.267 e $27.735 \mathrm{~kg} \mathrm{ha-1}$ de matéria seca da parte aérea, nos tratamentos $G$, A e $S$, respectivamente, as quais diferiram significativamente dos tratamentos T e $H: 17.040$ e $17.057 \mathrm{~kg} \mathrm{ha} \mathrm{g}^{-1}$, respectivamente. Concluiu-se que a adubação fosfatada, associada à reforma da pastagem, foi efetiva no incremento de produção da matéria seca de Brachiaria brizantha. O plantio direto do arroz ou da soja é aconselhável como prática de reforma de pastagens, por propiciar o efeito residual da adubação.
\end{abstract}

Termos de indexação: reforma de pastagem; solo; adubação, fósforo, fosfatagem.

\section{INTRODUCTION}

The felling of forests in the Amazon region for agricultural or livestock production is still boosting the regional and national deforestation rates, fuelling criticism, mainly internationally, of the loss of rainforest biodiversity, and the contribution to climate change and global warming, among other aspects.

Deforestation in the Amazon is usually based on the slash-and-burn practice, followed by some years of crop planting and subsequent pasture installation for livestock farming (Fujisaka et al., 1996; Fujisaka \& White, 1998; Martínez \& Zinck, 2004; Cerri et al., 2007). Pasture can also directly follow the removal of the economically most interesting trees, burning of the remaining vegetation at the end of the dry season and seeding of forage grasses (Feigl et al., 1995 and Moraes et al., 1996).

Burning, considered to be cheap, provides a satisfactory grass yield during the first years of pasture use due to the increased concentration of basic cations from the ashes of the forest (Dias Filho, 1998 
and Alfaia et al., 2004). However, soil fertility tends to decrease with time (Correa \& Reichardt, 1995 and Moraes et al., 1996), resulting in loss of grass vigor (Dias \& Griffith, 1998) and, after about 5-8 years of grazing activity, weed infestation increases significantly, while forage yield and quality decrease (Buschbacher et al., 1988; Fearnside, 1996). It is estimated that in the Amazon region more than 50 million hectares of forest have been converted into pasture and approximately half of this area is in some stage of degradation.

The gradual decline of soil fertility is suggested as the primary factor of pasture degradation (Euclides, 2000), mainly due to a reduction of $\mathrm{N}$ (Chapman et al., 1990; Boddey et al., 1996) and P availability (Dias Filho, 1998). However, McGrath et al. (2001) and Alfaia et al. (2004) concluded that conversion of forest to pasture in the Amazon does not affect the phosphorus content in soil, which is low in both ecosystems. When the degrading pasture loses the potential to maintain the cattle, new areas originally under forest are opened for incorporation into the livestock production system, again with forest felling and biomass burning (Buschbacher et al., 1988). Thus, the conventional farm in the manner described is not sustainable over time and the deforestation pressure is strong. As an alternative to burning, practices such as fertilization and soil amendment, associated (Davies et al., 1990; Bomfim, 2001) or not (Soares Filho et al., 1992, Costa et al., 1999; Carvalho, 1999) with overturning of the surface layer, are some of the recommended in pasture recovery to raise productivity to desirable levels.

Summing up, there is a six-stage degradation sequence after the deforestation of an area: 1- suitable for crop production, 2- unproductive for crops, 3suitable for animal husbandry, 4- unproductive for animal husbandry, 5-abandoned, degraded area and, 6- deforestation of a new area. Consequently, the maintenance of soil fertility and/or recovery of degraded pastures can help reduce deforestation in the Amazon. The main objective of this study was to evaluate the effects of some management practices of pasture recovery in Rondônia, quantifying some variables of soil fertility and forage productivity.

\section{MATERIAL AND METHODS}

This study was conducted on the Fazenda Nova Vida $\left(10^{\circ} 10^{\prime} 05^{\prime} \mathrm{S}\right.$ and $62^{\circ} 49^{\prime} 27^{\prime}$ W), in Ariquemes, BR $364 \mathrm{~km} \mathrm{472,} \mathrm{about} 250 \mathrm{~km}$ south of Porto Velho - RO (Moraes et al., 1996). The mean annual temperature and precipitation are, respectively, $25.5^{\circ} \mathrm{C}$ and $2,200 \mathrm{~mm}$, with a dry season between June and September (Bastos \& Diniz, 1982). The characteristic natural vegetation of the region is tropical forest.
The experimental area of three hectares was chosen in a previous study using geostatistics, which showed the homogeneity of soil in each block, in terms of sand and clay contents, $\mathrm{pH}, \delta^{13} \mathrm{C}, \delta^{15} \mathrm{~N}$, total $\mathrm{C}$ and $\mathrm{N}$ (Cerri et al., 2004). Brachiaria brizantha had been planted in 1983 in the area and the soil was classified as sandy clay loam Typic Hapludox (Latossolo Vermelho-Amarelo distrófico, textura média).

The experiment was arranged in a randomized block design with four replications and five treatments, totaling 20 plots. Each plot was 40 x $40 \mathrm{~m}$ $\left(1,600 \mathrm{~m}^{2}\right)$, with an area of $35 \times 35 \mathrm{~m}\left(1,225 \mathrm{~m}^{2}\right)$, where the treatments were applied in October 2001.

The treatments of recovery of forage productivity were:

C: Control - degraded pasture without any kind of management, consisting of Brachiaria brizantha + Panicum maximum +weeds; HE: Herbicide - handweeding and application of herbicide Padron to woody stumps and Garlon to palm species; fertilization with ammonium sulphate, $\mathrm{KCl}$ and micronutrients; sequential application of the herbicide Tordon (2-4 D); $\mathrm{HA}$ : harrowing + NPK + micronutrients - two diskings with a disk harrow and one with a leveling harrow followed by sowing of Brachiaria brizantha and fertilization with calcined phosphate (CP) incorporated with leveling harrow; fertilization with ammonium sulphate, $\mathrm{KCl}$ and micronutrients; $\mathrm{R}$ : No-tillage rice - desiccation in the whole area with glyphosate and Gramoxone, direct seeding of rice and fertilization with $\mathrm{CP}$, top dressing with ammonium sulphate, $\mathrm{KCl}$ and micronutrients; application of the postemergence herbicides Gladium and Ally and ant control; foliar fertilizer application of zinc sulphate, and sowing of Brachiaria brizantha after harvest; S: No-tillage soybean - glyphosate and Gramoxone application, tilling and fertilization of soybean with $\mathrm{CP}$; Fertilization with $\mathrm{KCl}$, application of postemergence herbicide Basagran and ant control. Application of manganese sulfate fertilizer to the leaves; sowing of Brachiaria brizantha after harvest.

Information related to timing of fertilizer application, fertilizer types, quantities of nutrients applied in the treatments and application methods are shown in tables 1 and 2 .

Base fertilization in the HA treatment with $\mathrm{CP}$ was applied on the same day as Brachiaria brizantha sowing and incorporation with leveling harrow.

Cattle was driven to the experimental area as of April 29, 2003. The number of heads and live weight varied according to season and pasture conditions, since the animals were kept in the area for 3-4 days to lower the grass to a height near the residual height of regrowth $(15 \mathrm{~cm})$. After removing the cattle, if necessary, the grass was cut with a mower to $15 \mathrm{~cm}$ height. The hay was not removed from the experimental area. 
Table 1. Schedule of fertilizer application in the recovery treatment of low-productivity pasture with the respective sources, nutrient contents and application form

\begin{tabular}{|c|c|c|c|c|c|c|c|c|c|c|}
\hline Date & Treat. & $\begin{array}{c}\text { Fertilizer } \\
\text { (applied quantity) }\end{array}$ & $\mathbf{N}$ & $\begin{array}{c}\text { Total } \\
\mathbf{P}\end{array}$ & $\mathrm{K}$ & $\mathbf{C a}$ & Mg & $\mathbf{S}$ & Micronutrients & $\begin{array}{c}\text { Application } \\
\text { form }\end{array}$ \\
\hline \multicolumn{2}{|l|}{$\mathrm{m} / \mathrm{d} / \mathrm{y}$} & & & & & $-\mathrm{k}$ & - $\mathrm{kg} \mathrm{ha}^{-1}$ & & & \\
\hline $11 / 08 / 01$ & HA & Calcined phophate (1020) & & 75.5 & & 204.0 & 71.4 & 40.8 & & Broadcast \\
\hline \multirow[t]{2}{*}{$11 / 21 / 01$} & $\mathrm{R}$ & Calcined phosphate (531) & & 39.3 & & 106.2 & 37.2 & 21.2 & & Topdressing \\
\hline & $\mathrm{S}$ & Calcined phosphate (531) & & 39.3 & & 106.2 & 37.2 & 21.2 & & Topdressing \\
\hline \multirow[t]{4}{*}{$11 / 24 / / 01$} & $1 \mathrm{R}$ & Ammonium sulfate $(60)$ & 12.6 & & & & & 14.4 & & Sidedressing \\
\hline & & $\mathrm{KCl}(80)$ & & & 42.4 & & & & $37.6 \mathrm{Cl}$ & Sidedressing \\
\hline & & Fritas BR12 (30) & & & & & & & $2.4 \mathrm{Zn} ; 0.24 \mathrm{Cu} ; 0.54 \mathrm{~B} ; 0.3 \mathrm{Mo} ; 0.9 \mathrm{Fe} ; 0.6 \mathrm{Mn}$ & Sidedressing \\
\hline & $\mathrm{S}$ & $\mathrm{KCl}(133.12)$ & & & 70.5 & & & & $62.6 \mathrm{Cl}$ & Sidedressing \\
\hline \multirow[t]{6}{*}{$12 / 03 / 01$} & $1 \mathrm{HE}$ & Ammonium sulfate (200) & 42.0 & & & & & 48.0 & & Broadcast \\
\hline & & $\mathrm{KCl}(50)$ & & & 26.5 & & & & $23.5 \mathrm{Cl}$ & Broadcast \\
\hline & & Fritas BR12 (30) & & & & & & & $2.4 \mathrm{Zn} ; 0.24 \mathrm{Cu} ; 0.54 \mathrm{~B} ; 0.3 \mathrm{Mo} ; 0.9 \mathrm{Fe} ; 0.6 \mathrm{Mn}$ & Broadcast \\
\hline & HA & Ammonium sulfate (200) & 42.0 & & & & & 48.0 & & Broadcast \\
\hline & & $\mathrm{KCl}(50)$ & & & 26.5 & & & & $23.5 \mathrm{Cl}$ & Broadcast \\
\hline & & Fritas BR12 (30) & & & & & & & $2.4 \mathrm{Zn} ; 0.24 \mathrm{Cu} ; 0.54 \mathrm{~B} ; 0.3 \mathrm{Mo} ; 0.9 \mathrm{Fe} ; 0.6 \mathrm{Mn}$ & Broadcast \\
\hline \multirow[t]{2}{*}{$01 / 4 / 02$} & $\mathrm{~S}$ & $\mathrm{MnSO}_{4}(1.2)$ & & & & & & 0.19 & $0.324 \mathrm{Mn}$ & Foliar \\
\hline & $\mathrm{R}$ & $\mathrm{ZnSO}_{4}(0.4)$ & & & & & & 0.04 & $0.084 \mathrm{Zn}$ & Foliar \\
\hline \multirow[t]{2}{*}{$01 / 6 / 02$} & $\mathrm{R}$ & Ammonium sulfate (100) & 21.0 & & & & & 24.0 & & Sidedressing \\
\hline & & $\mathrm{KCl}(35)$ & & & 18.5 & & & & $16.4 \mathrm{Cl}$ & Sidedressing \\
\hline
\end{tabular}

C: control; HA: harrowing; HE: herbicide; R: rice; S: soybean.

Table 2. Total nutrient amount applied in recovery treatments of low-productivity pasture. Note: treatment C was not fertilized

\begin{tabular}{lrrrrrrr}
\hline Treatment & N & P total & K & Ca & Mg & S & Micronutrients \\
& & & & & & & kg ha ${ }^{-1}$ \\
\cline { 2 - 6 } & & & & & & \\
HA & 42.0 & 75.48 & 26.5 & 204.0 & 71.40 & 88.8 & $23.5 \mathrm{Cl} ; 2.4 \mathrm{Zn} ; 0.24 \mathrm{Cu} ; 0.54 \mathrm{~B} ; 0.3 \mathrm{Mo} ; 0.9 \mathrm{Fe} ; 0.6 \mathrm{Mn}$. \\
R & 33.6 & 39.29 & 60.9 & 106.2 & 37.17 & 59.7 & $54.0 \mathrm{Cl} ; 2.48 \mathrm{Zn} ; 0.24 \mathrm{Cu} ; 0.54 \mathrm{~B} ; 0.3 \mathrm{Mo} ; 0.9 \mathrm{Fe} ; 0.6 \mathrm{Mn}$. \\
S & 0.0 & 39.29 & 70.5 & 106.2 & 37.17 & 21.4 & $62.6 \mathrm{Cl} ; 0.32 \mathrm{Mn}$. \\
HE & 42.0 & 0.00 & 26.5 & 0.0 & 0.00 & 48.0 & $23.5 \mathrm{Cl} ; 2.4 \mathrm{Zn} ; 0.24 \mathrm{Cu} ; 0.54 \mathrm{~B} ; 0.3 \mathrm{Mo} ; 0.9 \mathrm{Fe} ; 0.6 \mathrm{Mn}$.
\end{tabular}

C: control; HA: harrowing; HE: herbicide; R: rice; S: soybean.

Soil samples for chemical analysis were collected at three points per plot, in which mini-trenches $50 \times 50 \times 50 \mathrm{~cm}$ were opened, using two sides of the trench for soil sampling. These samples were mixed to obtain a representative composite sample from each plot and depth. Subsequently the samples were airdried, sieved (2 mm mesh) and laboratory-analyzed.

Soil samples for total nitrogen analysis were collected in the layers 0-5 and 5-10 cm after -3 (first evaluation 3 months prior to the experiment, in July 2001), 0, 5, 9, 12, 15, 28, and 39 months. Nitrogen content was determined by dry combustion in a LECO CN-2000 analyzer, in air-dried soil samples, sieved through $2 \mathrm{~mm}$ mesh and then ground to 100 mesh $(0.150 \mathrm{~mm})$.

Soil samples for analysis of available $\mathrm{P}$ and exchangeable bases were collected in the layers $0-5$, 5-10, 10-20 and 20-30 cm in month 0, before fertilization and 5, 28 and 39 months after the treatments. Available phosphorus and exchangeable basic cations $\left(\mathrm{Ca}^{2+}, \mathrm{Mg}^{2+}\right.$ and $\left.\mathrm{K}^{+}\right)$were extracted by ion-exchange resin (Raij et al., 2001). $\mathrm{Ca}^{2+}$ and $\mathrm{Mg}^{2+}$ were determined by atomic absorption spectrophotometer and $\mathrm{K}^{+}$by flame spectrometry. $\mathrm{P}$ was determined by colorimetry.

For the determination of the pasture biomass the grass was successively cut in 18-42 day intervals in a total of five assessments. The first sampling occurred in September 2004 and the last in March 2005. For sampling, wooden frames with an inner area of $0.5 \mathrm{~m}^{2}$ $(1.0 \times 0.5 \mathrm{~m})$ were placed randomly in the field, three per plot and evaluation; the grass was cut to a height of $15 \mathrm{~cm}$ from the soil. All plant material was weighed immediately after cutting (fresh weight) and then oven-dried at $65^{\circ} \mathrm{C}$ to constant weight (dry matter). Subsequently the entire area was grazed off to a pasture height of $15 \mathrm{~cm}$.

The mean daily forage accumulation was calculated based on the dry matter yield and the growth period, dividing the biomass collected in each frame by the number of days of the growth period after cutting (Pedreira et al., 2005). The monthly productivity was 
estimated by multiplying the mean daily rate of forage accumulation by the number of days in the month. The cumulative production from September 2004 to March 2005 was calculated by summing up the monthly yields of the sampling interval.

The results were subjected to analysis of variance (F test), considering the split-plot design (Cochran \& Cox, 1978), in which treatments were considered the main factor and sampling time the secondary factor, using ANOVA procedure of SAS (SAS Institute, 1987). The means were compared by the Tukey test at $5 \%$ probability level.

\section{RESULTS AND DISCUSSION}

\section{Total soil nitrogen}

The levels of total N (0.61-1.4 $\left.\mathrm{mg} \mathrm{g}^{-1}\right)$ (Table 3) were highest in the surface layer and decreased with increasing soil depth.

At the beginning of the experiment the overall mean $\mathrm{N}$ content was $1.16 \mathrm{mg} \mathrm{g}^{-1}$ in the $0-5 \mathrm{~cm}$ layer and close to that obtained by Neill et al. (1999) in a 21 year old pasture on the Fazenda Nova Vida. This is also compatible with values found in other studies of Neill et al. (1995), Neill et al. (1997) and Neill et al. (1998) in pastures of approximately 20 years.

In the first $10 \mathrm{~cm}$ depth no effects of the treatments and of the treatment-by-time interaction on total soil $\mathrm{N}$ were observed. However, the general $\mathrm{N}$ means obtained in different sampling periods $\left(x^{\prime}\right)$ differed from each other. The $\mathrm{N}$ values were lowest in the fifth month of the experiment, compared to months 0,9 , 28 and 39 , mainly in the 5-10 cm layer, which may be related to $\mathrm{N}$ immobilization or export via crop harvest at this time.

\section{Exchangeable phosphorus}

The exchangeable $\mathrm{P}$ contents (1.25-34.67 $\mathrm{mg} \mathrm{dm}^{-3}$ ) (Table 4) were highest near the soil surface and decreased with increasing depth.

At the beginning of the experiment, before fertilization, the amount of $\mathrm{P}$ in the soil were low, according to Sousa et al. (2001). P values tended to increase ( $p>0.05$ ) 632, 320 and $366 \%$ in the surface layer, in treatments $\mathrm{HA}, \mathrm{R}$ and $\mathrm{S}$, respectively, in the fifth month compared to month 0 , due to the effect of $P$ fertilization. This resulted in significant differences between the general means of the sampling periods $\left(x^{\prime}\right)$, where increased $\mathrm{P}$ contents were observed in the second sampling period and subsequent reduction in the last. The same trend was observed for $\mathrm{P}$ in the other layers.

The absence of significant differences between treatments in the surface layers may be related to the heterogeneous distribution of broadcast fertilizer, contributing to a greater variation of $\mathrm{P}$ to the depth of $10 \mathrm{~cm}$. This variation could also be attributed to natural spatial variability in the pasture soil, since forages have a high ability to compete for $\mathrm{P}$ in the soil

Table 3. Soil nitrogen in pasture recovery treatments ${ }^{(1)}$ in different sampling periods

\begin{tabular}{|c|c|c|c|c|c|c|c|c|}
\hline \multirow{2}{*}{ Treat. } & \multicolumn{8}{|c|}{ Sampling periods (month) } \\
\hline & -3 & 0 & 5 & 9 & 12 & 28 & 39 & x" \\
\hline & \multicolumn{8}{|c|}{$\begin{array}{l}\text { Soil nitrogen }\left(\mathrm{mg} \mathrm{g}^{-1}\right) \\
0-5 \mathrm{~cm}\end{array}$} \\
\hline $\begin{array}{l}\mathrm{C} \\
\mathrm{HA} \\
\mathrm{HE} \\
\mathrm{R} \\
\mathrm{S}\end{array}$ & $\begin{array}{l}1.19 \\
1.22 \\
1.08 \\
1.10 \\
1.08\end{array}$ & $\begin{array}{l}1.31 \\
1.01 \\
1.11 \\
1.20 \\
1.19\end{array}$ & $\begin{array}{l}0.96 \\
1.00 \\
0.99 \\
0.93 \\
1.14\end{array}$ & $\begin{array}{l}1.24 \\
0.99 \\
1.19 \\
1.23 \\
1.27\end{array}$ & $\begin{array}{l}1.20 \\
1.09 \\
1.10 \\
1.08 \\
1.21\end{array}$ & $\begin{array}{l}1.34 \\
1.39 \\
1.20 \\
1.35 \\
1.09\end{array}$ & $\begin{array}{l}1.40 \\
1.22 \\
1.36 \\
1.16 \\
1.37\end{array}$ & $\begin{array}{l}1.23 \mathrm{a} \\
1.13 \mathrm{a} \\
1.15 \mathrm{a} \\
1.15 \mathrm{a} \\
1.19 \mathrm{a}\end{array}$ \\
\hline $\mathrm{x}^{\prime}$ & $1.13 \mathrm{BC}$ & $1.16 \mathrm{AB}$ & $1.00 \mathrm{C}$ & $\begin{array}{r}1.18 \mathrm{AB} \\
5-10\end{array}$ & $1.14 \mathrm{BC}$ & $1.27 \mathrm{AB}$ & $1.30 \mathrm{~A}$ & \\
\hline $\begin{array}{l}\mathrm{C} \\
\mathrm{HA} \\
\mathrm{HE} \\
\mathrm{R} \\
\mathrm{S}\end{array}$ & $\begin{array}{l}0.89 \\
0.88 \\
0.88 \\
0.87 \\
0.80\end{array}$ & $\begin{array}{l}0.93 \\
0.97 \\
0.94 \\
0.93 \\
0.86\end{array}$ & $\begin{array}{l}0.71 \\
0.81 \\
0.61 \\
0.75 \\
0.69\end{array}$ & $\begin{array}{l}1.09 \\
0.87 \\
0.93 \\
1.09 \\
0.95\end{array}$ & $\begin{array}{l}0.86 \\
0.94 \\
0.87 \\
0.88 \\
0.87\end{array}$ & $\begin{array}{l}0.97 \\
1.11 \\
1.09 \\
1.03 \\
0.89\end{array}$ & $\begin{array}{l}0.99 \\
0.94 \\
1.06 \\
0.88 \\
1.03\end{array}$ & $\begin{array}{l}0.92 \mathrm{a} \\
0.93 \mathrm{a} \\
0.91 \mathrm{a} \\
0.92 \mathrm{a} \\
0.87 \mathrm{a}\end{array}$ \\
\hline $\mathrm{x}^{\prime}$ & $0.86 \mathrm{C}$ & $0.93 \mathrm{ABC}$ & $0.72 \mathrm{D}$ & $0.99 \mathrm{AB}$ & $0.88 \mathrm{BC}$ & $1.02 \mathrm{~A}$ & $0.98 \mathrm{AB}$ & \\
\hline
\end{tabular}

(1) Fertilization applied in month 0, after soil sampling. C: control; HA: harrowing, HE: herbicide, R: rice and S: soybean. n: 4; $\boldsymbol{x}$ ': means of sampling periods, x": treatment mean. n: 4. Means followed by the same letter or without letters are not statistically different by the Tukey test at $5 \%$. Lowercase letters compare means in columns and capital letters means in the rows. For the 0-5 cm layer: $\mathrm{CV}=12.81, \mathrm{~F} \_$treat $=2.03 \mathrm{~ns}, \mathrm{~F} \_$time $=8.57 * *$, F_treat ${ }^{*}$ time $=1.60 \mathrm{~ns} ;$ for $5-10 \mathrm{~cm}: \mathrm{CV}=12.74, \mathrm{~F} \_$treat $=0.51$ ns; F_time $=15.69 * *$, F_treat $*$ time $=1.52 \mathrm{~ns}$. 
Table 4. Soil exchangeable phosphorus in pasture recovery treatments in four sampling periods

\begin{tabular}{|c|c|c|c|c|c|}
\hline \multirow{2}{*}{ Treat. } & \multicolumn{5}{|c|}{$\begin{array}{l}\text { Exchangeable phosphorus } \\
\text { Sampling periods (month) }\end{array}$} \\
\hline & 0 & 5 & 28 & 39 & $x "$ \\
\hline & \multicolumn{4}{|c|}{$\mathrm{mg} \mathrm{dm}^{-3}$} & $0-5 \mathrm{~cm}$ \\
\hline $\mathrm{C}$ & 6.59 & 10.00 & 10.00 & 9.75 & $9.08 \mathrm{a}$ \\
\hline HA & 4.73 & 34.67 & 16.50 & 11.25 & $16.79 \mathrm{a}$ \\
\hline $\mathrm{HE}$ & 6.34 & 10.25 & 5.50 & 9.25 & $7.83 \mathrm{a}$ \\
\hline $\mathrm{R}$ & 5.83 & 24.50 & 13.25 & 11.25 & $13.71 \mathrm{a}$ \\
\hline S & 6.08 & 28.33 & 20.50 & 20.25 & $18.79 \mathrm{a}$ \\
\hline$x^{\prime}$ & $5.91 \mathrm{~B}$ & $21.55 \mathrm{~A}$ & $13.15 \mathrm{~B}$ & $12.35 \mathrm{~B}$ & \\
\hline \multicolumn{6}{|c|}{$5-10 \mathrm{~cm}$} \\
\hline $\mathrm{C}$ & 5.32 & 4.75 & 7.00 & 7.25 & $6.08 \mathrm{a}$ \\
\hline HA & 4.31 & 7.25 & 10.25 & 8.25 & $7.51 \mathrm{a}$ \\
\hline $\mathrm{HE}$ & 4.48 & 4.50 & 3.50 & 7.00 & $4.87 \mathrm{a}$ \\
\hline $\mathrm{R}$ & 4.22 & 13.50 & 10.25 & 6.75 & $8.68 \mathrm{a}$ \\
\hline S & 4.05 & 8.25 & 6.75 & 4.75 & $5.95 \mathrm{a}$ \\
\hline$x^{\prime}$ & $4.47 \mathrm{~A}$ & $7.65 \mathrm{~A}$ & $7.55 \mathrm{~A}$ & $6.80 \mathrm{~A}$ & \\
\hline \multicolumn{6}{|c|}{$10-20 \mathrm{~cm}$} \\
\hline $\mathrm{C}$ & $4.22 \mathrm{aB}$ & $4.75 \mathrm{aAB}$ & $7.00 \mathrm{aA}$ & $3.25 \mathrm{aB}$ & $4.81 \mathrm{a}$ \\
\hline HA & $4.05 \mathrm{aAB}$ & $5.00 \mathrm{aAB}$ & $6.25 \mathrm{abA}$ & $3.75 \mathrm{aB}$ & $4.76 \mathrm{a}$ \\
\hline $\mathrm{HE}$ & $3.30 \mathrm{aA}$ & $3.75 \mathrm{aA}$ & $2.25 \mathrm{cA}$ & $3.75 \mathrm{aA}$ & $3.26 \mathrm{~b}$ \\
\hline $\mathrm{R}$ & $2.62 \mathrm{aA}$ & $4.75 \mathrm{aA}$ & $4.25 \mathrm{bcA}$ & $4.00 \mathrm{aA}$ & $3.90 \mathrm{ab}$ \\
\hline $\mathrm{S}$ & $2.79 \mathrm{aB}$ & $4.00 \mathrm{aAB}$ & $5.50 \mathrm{abA}$ & $4.50 \mathrm{aAB}$ & $4.20 \mathrm{ab}$ \\
\hline$x^{\prime}$ & $3.39 \mathrm{~B}$ & $4.45 \mathrm{AB}$ & $5.05 \mathrm{~A}$ & $3.85 \mathrm{~B}$ & \\
\hline \multicolumn{6}{|c|}{$20-30 \mathrm{~cm}$} \\
\hline $\mathrm{C}$ & $3.04 \mathrm{aB}$ & $3.25 \mathrm{aB}$ & $5.50 \mathrm{aA}$ & $2.75 \mathrm{aB}$ & $3.63 \mathrm{a}$ \\
\hline HA & $2.96 \mathrm{aA}$ & $3.50 \mathrm{aA}$ & $4.25 \mathrm{aA}$ & $2.50 \mathrm{aA}$ & $3.30 \mathrm{a}$ \\
\hline $\mathrm{HE}$ & $2.03 \mathrm{aA}$ & $3.00 \mathrm{aA}$ & $1.25 \mathrm{bA}$ & $2.25 \mathrm{aA}$ & $2.13 \mathrm{~b}$ \\
\hline $\mathrm{R}$ & $1.94 \mathrm{aB}$ & $3.25 \mathrm{aAB}$ & $4.50 \mathrm{aA}$ & $2.00 \mathrm{aB}$ & $2.92 \mathrm{ab}$ \\
\hline $\mathrm{S}$ & $1.86 \mathrm{aB}$ & $4.25 \mathrm{aA}$ & $4.25 \mathrm{aA}$ & $3.25 \mathrm{aAB}$ & $3.40 \mathrm{a}$ \\
\hline$x^{\prime}$ & $2.36 \mathrm{~B}$ & $3.45 \mathrm{~A}$ & $3.95 \mathrm{~A}$ & $2.55 \mathrm{~B}$ & \\
\hline
\end{tabular}

(1) Fertilization applied in month 0, after soil sampling. C: control; HA: harrowing, HE: herbicide, R: rice and S: soybean. n: $4 ; \boldsymbol{x}$ : means of sampling periods, x": treatment mean. n: 4. Means followed by the same letter or without letters are not statistically different by the Tukey test at $5 \%$. Lowercase letters compare means in columns and capital letters means in the rows. For the $0-5 \mathrm{~cm}$ layer: $\mathrm{CV}=73.84, \mathrm{~F}_{-}$treat $=2.98 \mathrm{~ns}, \mathrm{~F}_{-}$time $=8.62$ $* *$. F treat $*$ time $=1.20 \mathrm{~ns} ;$ for $5-10 \mathrm{~cm}: \mathrm{CV}=68.0, \mathrm{~F}$ treat $=$ $3.17 \mathrm{~ns} ; \mathrm{F}$-time $=2.15 \mathrm{~ns}, \mathrm{~F}$-treat $*$ time $=0.94 \mathrm{~ns}$, for 10 $20 \mathrm{~cm}: \mathrm{CV}=30.94, \mathrm{~F}_{\text {_treat }}=4.19 *$, F_time $=6.19 * \mathrm{~F}_{\text {_treat }} *$ time $=2.27 *$; for $20-30 \mathrm{~cm}: \mathrm{CV}=31.03 ; \mathrm{F}$-treat $=6.83 * *=$ $12.33^{* *}$ F_time, F_treat $*$ time $=2.86 * *$.

and recycle it (Garcia-Montiel et al., 2000). According to Corazza (2002), low-productivity pasture accumulates $\mathrm{P}$ in the soil under the tussocks, at the expense of the areas between tussocks. Moreover, Cameron (1996) found variations in P availability during the rainy and dry seasons in Australia, suggesting a seasonal effect on $\mathrm{P}$ availability.
Although $\mathrm{R}$ and $\mathrm{S}$ were treated with little more than half the dose applied in treatment HA (Table 1), a residual effect of $\mathrm{P}$ was observed in these treatments. The increased $\mathrm{P}$ levels observed in these treatments in the surface layer in the $5^{\text {th }}$ month of the experiment tended to decrease in the third sampling period. However, according to Sousa et al. (2001), the P levels in the fertilized treatments were still adequate 39 months after beginning the experiment.

Phosphate fertilization did not affected $\mathrm{P}$ levels of the 10-30 cm layer. However, treatment-by-time interaction was observed from $10 \mathrm{~cm}$ depth downwards. Differences between treatments were only observed in the $28^{\text {th }}$ month. At this time the $\mathrm{P}$ levels in the HE treatment were lower in the layers 10-20 and 20-30 cm than in the other treatments, which is consistent with the fact that P-fertilization had not been applied. Fertilization with other nutrients in HE treatment must have stimulated pasture growth and consequently $\mathrm{P}$ uptake, particularly when compared to the control.

\section{Exchangeable cations $\left(\mathrm{Ca}^{2+}, \mathrm{Mg}^{2+}\right.$ and $\left.\mathrm{K}^{+}\right)$}

The values of $\mathrm{Ca}^{2+}, \mathrm{Mg}^{2+}$ and $\mathrm{K}^{+}$(Table 5) varied from 4.5-39.5 mmol $\mathrm{dm}^{-3}$ for $\mathrm{Ca}^{2+}, 1.25-$ $13.75 \mathrm{mmol}_{\mathrm{c}} \mathrm{dm}^{-3}$ for $\mathrm{Mg}^{2+}$ and $0.2-3.7 \mathrm{mmol}_{\mathrm{c}} \mathrm{dm}^{-3}$ for $\mathrm{K}^{+}$. As expected, the concentration of these cations was higher at the surface and decreased with increasing soil depth. This can be attributed to ash deposition on the pasture soil surface from biomass burning of the remains of native vegetation prior to pasture establishment and from eventual pasture fires, as well as to the specific pattern of nutrient cycling in the soil plant cover, combined with subsurface leaching (Moraes et al., 1996; Alfaia et al., 2004; Araújo et al., 2004) and to fertilization in the experimental area.

Initially, high soil $\mathrm{Ca}^{2+}$ contents for B.brizantha can be noted to a depth of $20 \mathrm{~cm}$ (Werner et al., 1996). However, $\mathrm{Mg}^{2+}$ content can be classified as low to medium. This pattern may be due to rapid cycling of calcium of the grass leaves and fine roots (McGrath et al., 2001).

Effects of pasture recovery treatments on the basic cations were detected in the fifth month of the experiment. At this time, $\mathrm{Ca}^{2+}$ content had increased by approximately 95,85 and $73 \%$ in the $0-5 \mathrm{~cm}$ layer, in treatments HA, $\mathrm{R}$ and $\mathrm{S}$, respectively, compared to the beginning of the experiment (month 0 ). In the same month and layer, $\mathrm{Mg}^{2+}$ had increased by 110 and $63 \%$ in treatments HA and S, respectively, and $\mathrm{K}^{+}$had increased by $55 \%$ in HA.

The high $\mathrm{Ca}^{2+}$ and $\mathrm{Mg}^{2+}$ concentrations in the surface layer of the treatments in the fifth month were due to fertilization with $\mathrm{CP}$, which contains these cations. In treatment $\mathrm{R}$, despite equal applications of phosphate fertilizer as in the $\mathrm{S}$ treatment, the $\mathrm{Mg}^{2+}$ contents had not increased after five months, 
Table 5. Soil exchangeable cations in pasture recovery treatments in four sampling periods. Note: Fertilization applied in month 0 , after soil sampling

\begin{tabular}{|c|c|c|c|c|c|c|c|c|c|c|c|c|}
\hline \multirow{2}{*}{ Treat. } & \multicolumn{4}{|c|}{ Sampling periods (months) } & \multicolumn{4}{|c|}{ Sampling periods (months) } & \multicolumn{4}{|c|}{ Sampling periods (months) } \\
\hline & $\mathbf{0}$ & 5 & 28 & 39 & $\mathbf{0}$ & 5 & 28 & 39 & $\mathbf{0}$ & 5 & 28 & 39 \\
\hline & \multicolumn{4}{|c|}{$\mathrm{Ca}^{2+}\left(\mathrm{mmol}_{\mathrm{c}} \mathrm{dm}^{-3}\right)$} & \multicolumn{4}{|c|}{$\begin{array}{c}\mathrm{Mg}^{2+}\left(\mathrm{mmol}_{\mathrm{c}} \mathrm{dm}^{-3}\right)- \\
0-5 \mathrm{~cm}\end{array}$} & \multicolumn{4}{|c|}{$\mathrm{K}^{+}\left(\mathrm{mmol}_{\mathrm{c}} \mathrm{dm}^{-3}\right)$} \\
\hline $\mathrm{C}$ & $24.77 \mathrm{aA}$ & $27.00 \mathrm{bA}$ & $21.25 \mathrm{aA}$ & $22.25 \mathrm{aA}$ & $7.92 \mathrm{aA}$ & $8.50 \mathrm{bcA}$ & $5.25 \mathrm{aA}$ & $8.75 \mathrm{aA}$ & $2.56 \mathrm{aA}$ & $3.00 \mathrm{abA}$ & $2.15 \mathrm{aAB}$ & $1.00 \mathrm{bB}$ \\
\hline HA & $19.86 \mathrm{aB}$ & $38.75 \mathrm{aA}$ & $20.00 \mathrm{aB}$ & $16.00 \mathrm{aB}$ & $6.54 \mathrm{aB}$ & $13.75 \mathrm{aA}$ & $6.75 \mathrm{aB}$ & $7.25 \mathrm{aB}$ & $2.38 \mathrm{aB}$ & $3.70 \mathrm{aA}$ & $1.98 \mathrm{aB}$ & $2.75 \mathrm{aAB}$ \\
\hline $\mathrm{HE}$ & $18.24 \mathrm{aA}$ & $24.00 \mathrm{bA}$ & $15.25 \mathrm{aA}$ & $21.75 \mathrm{aA}$ & $6.68 \mathrm{aA}$ & $8.00 \mathrm{bcA}$ & $5.00 \mathrm{aA}$ & $8.00 \mathrm{aA}$ & $2.18 \mathrm{aA}$ & $2.50 \mathrm{abA}$ & $1.63 \mathrm{aA}$ & $2.28 \mathrm{abA}$ \\
\hline $\mathrm{R}$ & $20.78 \mathrm{aB}$ & $38.50 \mathrm{aA}$ & $17.50 \mathrm{aB}$ & $13.50 \mathrm{aB}$ & $7.26 \mathrm{aA}$ & $7.75 \mathrm{cA}$ & $5.75 \mathrm{aA}$ & $6.75 \mathrm{aA}$ & $2.82 \mathrm{aA}$ & $1.83 \mathrm{bA}$ & $1.83 \mathrm{aA}$ & $2.48 \mathrm{aA}$ \\
\hline $\mathrm{S}$ & $22.83 \mathrm{aB}$ & $39.50 \mathrm{aA}$ & $17.00 \mathrm{aB}$ & $19.50 \mathrm{aB}$ & $7.21 \mathrm{aB}$ & $11.75 \mathrm{abA}$ & $4.33 \mathrm{aB}$ & $7.75 \mathrm{aB}$ & $2.40 \mathrm{aA}$ & $1.90 \mathrm{bA}$ & $2.00 \mathrm{aA}$ & $2.28 \mathrm{abA}$ \\
\hline \multirow[t]{2}{*}{$x^{\prime}$} & $21.30 \mathrm{~B}$ & $33.55 \mathrm{~A}$ & $18.20 \mathrm{~B}$ & $18.60 \mathrm{~B}$ & $7.12 \mathrm{~B}$ & $9.95 \mathrm{~A}$ & $5.42 \mathrm{C}$ & $7.70 \mathrm{~B}$ & $2.47 \mathrm{~A}$ & $2.59 \mathrm{~A}$ & $1.92 \mathrm{~B}$ & $2.16 \mathrm{AB}$ \\
\hline & \multicolumn{12}{|c|}{$5-10 \mathrm{~cm}$} \\
\hline $\mathrm{C}$ & $16.12 \mathrm{aA}$ & $15.25 \mathrm{aA}$ & $13.25 \mathrm{aA}$ & $19.75 \mathrm{aA}$ & 4.51 & 4.50 & 3.00 & 4.00 & 1.83 & 1.18 & 1.08 & 1.43 \\
\hline $\mathrm{HA}$ & $17.30 \mathrm{aA}$ & $21.25 \mathrm{aA}$ & $16.75 \mathrm{aA}$ & $14.50 \mathrm{aA}$ & 5.64 & 6.00 & 4.75 & 4.25 & 2.08 & 1.20 & 1.45 & 1.83 \\
\hline $\mathrm{HE}$ & $12.60 \mathrm{aA}$ & $13.25 \mathrm{aA}$ & $9.50 \mathrm{aA}$ & $15.75 \mathrm{aA}$ & 3.71 & 4.50 & 2.75 & 4.50 & 1.27 & 0.78 & 0.83 & 1.65 \\
\hline $\mathrm{R}$ & $15.45 \mathrm{aAB}$ & $22.25 \mathrm{aA}$ & $12.75 \mathrm{aB}$ & $10.75 \mathrm{aB}$ & 3.93 & 5.50 & 3.75 & 4.00 & 1.57 & 1.83 & 0.95 & 1.75 \\
\hline $\mathrm{S}$ & $14.72 \mathrm{aA}$ & $19.00 \mathrm{aA}$ & $14.50 \mathrm{aA}$ & $11.25 \mathrm{aA}$ & 3.64 & 5.50 & 3.25 & 3.50 & 1.27 & 1.53 & 0.95 & 1.48 \\
\hline \multirow[t]{2}{*}{$x}$, & $15.24 \mathrm{AB}$ & $18.20 \mathrm{~A}$ & $13.35 \mathrm{~B}$ & $14.40 \mathrm{~B}$ & $4.28 \mathrm{~B}$ & $5.20 \mathrm{~A}$ & $3.50 \mathrm{~B}$ & $4.05 \mathrm{~B}$ & $1.60 \mathrm{~A}$ & $1.30 \mathrm{AB}$ & $1.05 \mathrm{~B}$ & $1.63 \mathrm{~A}$ \\
\hline & \multicolumn{12}{|c|}{$10-20 \mathrm{~cm}$} \\
\hline $\mathrm{C}$ & $10.07 \mathrm{aA}$ & $9.75 \mathrm{aA}$ & $13.25 \mathrm{aA}$ & $13.50 \mathrm{aA}$ & 2.96 & 3.25 & 1.75 & 2.75 & 1.18 & 0.65 & 0.63 & 0.35 \\
\hline $\mathrm{HA}$ & $14.11 \mathrm{aA}$ & $13.00 \mathrm{aA}$ & $9.17 \mathrm{aA}$ & $9.50 \mathrm{abA}$ & 3.40 & 3.75 & 2.75 & 2.75 & 1.27 & 0.85 & 1.03 & 0.95 \\
\hline $\mathrm{HE}$ & $9.38 \mathrm{aA}$ & $10.50 \mathrm{aA}$ & $7.25 \mathrm{aA}$ & $10.75 \mathrm{abA}$ & 2.73 & 4.00 & 1.75 & 2.75 & 0.83 & 0.98 & 0.35 & 0.80 \\
\hline $\mathrm{R}$ & $10.28 \mathrm{aAB}$ & $15.25 \mathrm{aA}$ & $9.00 \mathrm{aB}$ & $6.75 \mathrm{bB}$ & 2.40 & 2.75 & 2.25 & 2.75 & 0.92 & 0.83 & 0.45 & 1.18 \\
\hline $\mathrm{S}$ & $11.11 \mathrm{aA}$ & $12.00 \mathrm{aA}$ & $9.00 \mathrm{aA}$ & $9.00 \mathrm{abA}$ & 2.83 & 3.00 & 1.75 & 2.75 & 1.16 & 1.13 & 0.38 & 1.15 \\
\hline \multirow[t]{2}{*}{$x^{\prime}$} & $10.99 \mathrm{AB}$ & $12.10 \mathrm{~A}$ & $9.53 \mathrm{~B}$ & $9.90 \mathrm{AB}$ & $2.86 \mathrm{~A}$ & $3.35 \mathrm{~A}$ & $2.05 \mathrm{~B}$ & $2.75 \mathrm{~A}$ & $1.07 \mathrm{~A}$ & $0.89 \mathrm{AB}$ & $0.57 \mathrm{~B}$ & $0.89 \mathrm{AB}$ \\
\hline & \multicolumn{12}{|c|}{$20-30 \mathrm{~cm}$} \\
\hline $\mathrm{C}$ & 7.04 & 5.75 & 8.75 & 9.00 & 2.22 & 2.50 & 2.00 & 2.25 & $0.94 \mathrm{aA}$ & $0.18 \mathrm{bA}$ & $0.85 \mathrm{aA}$ & $0.65 \mathrm{aA}$ \\
\hline $\mathrm{HA}$ & 11.22 & 8.75 & 7.75 & 7.75 & 2.60 & 2.50 & 2.00 & 2.75 & $0.68 \mathrm{aA}$ & $0.33 \mathrm{abA}$ & $0.83 \mathrm{aA}$ & $1.03 \mathrm{aA}$ \\
\hline $\mathrm{HE}$ & 6.11 & 7.00 & 5.25 & 8.50 & 1.77 & 2.75 & 1.50 & 2.50 & $0.65 \mathrm{aA}$ & $0.25 \mathrm{abA}$ & $0.45 \mathrm{aA}$ & $1.03 \mathrm{aA}$ \\
\hline $\mathrm{R}$ & 8.82 & 9.75 & 6.25 & 4.50 & 1.92 & 2.50 & 1.75 & 2.25 & $0.59 \mathrm{aAB}$ & $1.03 \mathrm{aA}$ & $0.20 \mathrm{aB}$ & $1.08 \mathrm{aA}$ \\
\hline $\mathrm{S}$ & 7.72 & 8.25 & 6.75 & 7.25 & 1.89 & 2.50 & 1.25 & 2.50 & $0.90 \mathrm{aAB}$ & $0.83 \mathrm{aAB}$ & $0.35 \mathrm{aB}$ & $1.30 \mathrm{aA}$ \\
\hline$x^{\prime}$ & $8.18 \mathrm{~A}$ & $7.90 \mathrm{~A}$ & $6.95 \mathrm{~A}$ & $7.40 \mathrm{~A}$ & $2.08 \mathrm{BC}$ & $2.55 \mathrm{~A}$ & $1.70 \mathrm{C}$ & $2.45 \mathrm{AB}$ & $0.75 \mathrm{AB}$ & 0.52 B & $0.54 \mathrm{~B}$ & $1.02 \mathrm{~A}$ \\
\hline
\end{tabular}

C: control; HA: harrowing, HE: herbicide, R: rice and S: soybean. n: 4; $\boldsymbol{x}$ ': means of sampling periods, x": treatment mean. n: 4. Means followed by the same letter or without letters are not statistically different by the Tukey test at $5 \%$. Lowercase letters compare means in columns and capital letters means in the rows. Calcium for the $0-5 \mathrm{~cm}$ layer: CV $=20.43, \mathrm{~F} \_$treat $=0.80 \mathrm{~ns}$, F_time $=47.63^{* *}, F_{-}$treat ${ }^{*}$ time $=4.10^{* *}$; for the $5-10 \mathrm{~cm}$ layer: $\mathrm{CV}=27.49, \mathrm{~F}$-treat $=1.30 \mathrm{~ns}, \mathrm{~F} \_$time $=4.91 * * * \mathrm{~F}_{-}$trat $*$ time $=$ $2.01^{*}$; for the $10-20 \mathrm{~cm}$ layer: $\mathrm{CV}=28.27, \mathrm{~F}_{-}$treat $=0.65 \mathrm{~ns}, \mathrm{~F} \_$time $=2.97^{*}$, F_treat ${ }^{*}$ time $=2.35^{*}$; for the $20-30 \mathrm{~cm}$ layer: $\mathrm{CV}=$ $33.01, F_{-}$treat $=1.1 \mathrm{~ns}, \mathrm{~F}_{-}$time $=0.94 \mathrm{~ns}, \mathrm{~F}_{-}$treat $*$ time $=1.84 \mathrm{~ns} ;$ Magnesium for the $0-5 \mathrm{~cm}$ layer: CV $=25.98, \mathrm{~F}_{-}$treat $=2.04 \mathrm{~ns}$, F_time $=18.24^{* *}, \mathrm{~F}_{-}$treat $*$ time $=2.38^{*}$, for the $5-10 \mathrm{~cm}$ layer: $\mathrm{CV}=24.41, \mathrm{~F}_{-}$treat $=3.15 \mathrm{~ns}, \mathrm{~F} \_$time $=9.29^{* * *}, \mathrm{~F}_{-}$treat ${ }^{*}$ time $=$ $0.97 \mathrm{~ns}$; for the $10-20 \mathrm{~cm}$ layer: $\mathrm{CV}=27.56, \mathrm{~F}_{-}$treat $=0.99 \mathrm{~ns}, \mathrm{~F}_{-}$time $=9.98^{* *}, \overline{\mathrm{F}}_{-}$treat $*$ time $=0.81 \mathrm{~ns}$; for the $20-30 \mathrm{~cm}$ layer: $\mathrm{CV}$ $=24.63, \mathrm{~F}$-treat $=1.78 \mathrm{~ns}, \mathrm{~F}$ _time $=10.25^{* *}, \mathrm{~F}$ _treat ${ }^{*}$ time $=0.74 \mathrm{~ns}$ and; Potassium for the $0-5 \mathrm{~cm}$ layer: CV $=27.84, \mathrm{~F} \_$treat $=2,26$ ns, F_time $=4.58^{* *}, F_{-}$treat ${ }^{*}$ time $=3.12^{* *}$, for the $5-10 \mathrm{~cm}$ layer: $\mathrm{CV}=37.88, \mathrm{~F}_{-}$treat $=1.96 \mathrm{~ns}, \mathrm{~F}_{-}$time $=5.36^{* *}, \mathrm{~F}_{-}$treat ${ }^{*}$ time $=1.03 \mathrm{~ns}$; for the $10-20 \mathrm{~cm}$ layer: $\mathrm{CV}=56.66, \mathrm{~F}$ treat $=3.49 \mathrm{~ns}, \mathrm{~F}$-time $=3.80^{*}, \mathrm{~F}$-treat $*$ time $=1.04 \mathrm{~ns}$; for the $20-30 \mathrm{~cm}$ layer: $\mathrm{CV}=58.4, \mathrm{~F}_{-}$treat $=1.02 \mathrm{~ns}, \mathrm{~F}_{-}$time $=6.34^{* *}, \mathrm{~F}_{-}$treat ${ }^{*}$ time $=2.15^{*}$.

suggesting nutrient uptake by rice plants and export through harvest.

The highest $\mathrm{K}^{+}$content was found in treatment $\mathrm{HA}$, in the surface soil layer in the fifth month of the experiment. This reflects $\mathrm{K}$ fertilization and efficient cycling by reestablished Brachiaria (Alfaia et al., 2004, Torres \& Pereira, 2008). A contrasting behavior was observed in the treatments $\mathrm{R}$ and $\mathrm{S}$, where the contents of this ion were lowest at this time due to the inefficiency of cycling because of the harvest of rice and soybean. In these treatments, the lack of vegetation, combined with high $\mathrm{Ca}^{2+}$ contents in the system, may have favored the displacement of $\mathrm{K}^{+}$to the 20-30 cm layer. Carvalho (1999) reported that liming promoted potassium leaching.

After 28 months, the $\mathrm{Ca}^{2+}$ values in the treatments $\mathrm{HA}, \mathrm{R}, \mathrm{S}$ and $\mathrm{Mg}^{2+}$ in HA and $\mathrm{S}$ were statistically similar to those found at the beginning of the experiment in the surface layer. The differences between treatments for the levels of these elements after 28 months in this layer were not significant either.

In the $39^{\text {th }}$ month, in the $\mathrm{C}$ treatment in the $0-$ $5 \mathrm{~cm}$ layer, $\mathrm{K}^{+}$contents were statistically lower than in HA and R. The differences between treatments for $\mathrm{K}^{+}$were not significant at the beginning of the experiment (month 0 ). 
In assessments of pasture productivity, from September 2004 to March 2005 (Figure 1), a lower dry weight production of plant shoots in treatment $\mathrm{C}$ was stated. This probably resulted in reduced ground cover and generally lower nutrient use in this treatment, exposing particularly $\mathrm{K}^{+}$to leaching through the profile, which explains the low soil $\mathrm{K}^{+}$ contents in January 2005 , i.e., in the $39^{\text {th }}$ month, in the period of most intense rain.

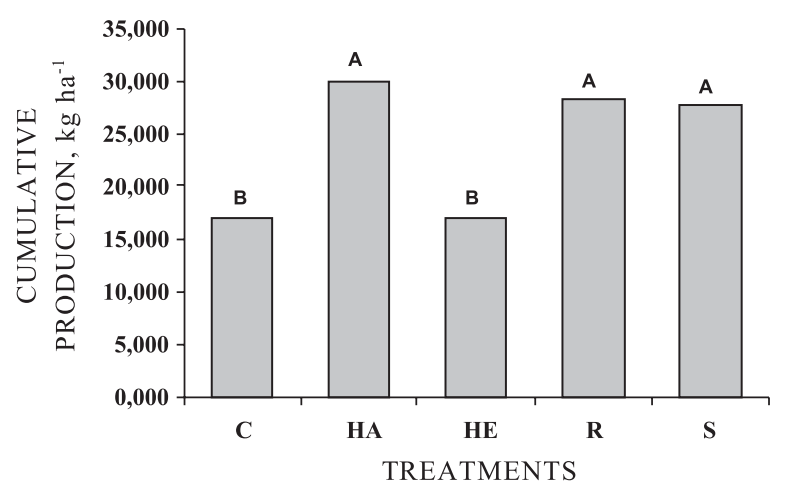

Figure 1. Cumulative production of Brachiaria brizantha in treatments $\mathrm{C}, \mathrm{HA}, \mathrm{HE}, \mathrm{R}$ and $\mathrm{S}$ from September 2004 to March 2005. Capital letters compare treatments with each other $(p<0.01)$.

The trend observed in the surface layer, with lower concentrations of basic cations in the $28^{\text {th }}$ month compared to the fifth, persisted in the deeper layers.

\section{Productivity of Brachiaria brizantha}

The results of cumulative production from September 2004 to March 2005 indicated that the treatment $\mathrm{HA}$, with $30,025 \mathrm{~kg} \mathrm{ha}^{-1}$, was not statistically different from $\mathrm{R}$ and $\mathrm{S}$, with 28,267 and $27,735 \mathrm{~kg} \mathrm{ha}^{-1}$, respectively (Figure 1). Yields in these treatments were higher than in the treatments $\mathrm{C}$ (17,040 $\left.\mathrm{kg} \mathrm{ha}^{-1}\right)$ and HE $\left(17,058 \mathrm{~kg} \mathrm{ha}^{-1}\right)$; there was no fertilizer application in $\mathrm{C}$ and in $\mathrm{HE}$ only $\mathrm{P}$ was not applied. This leads to the inference that $\mathrm{P}$ must be limiting the productivity of these pastures considerably. Some studies indicate $\mathrm{P}$ as the main limiting factor for pasture productivity in the Amazon (Urquiaga et al., 1998, Dias-Filho et al., 2001).

A comparison of the dry matter yield in treatment $\mathrm{C}$, with lowest yield, with that of the most productive treatment, HA, showed a difference of $81 \%$. According to Carvalho (1999), tillage promotes Brachiaria seed germination, which can cause an increase in pasture production.

The studies of Arruda et al. (1987), Carvalho et al. (1990), Soares Filho et al. (1992), Costa et al. (1999), and Costa et al. (2003) indicate successful pasture recovery by the use of NPK with annual or biennial applications of these nutrients. However, $\mathrm{N}$ fertilization in the initial phase of the HE treatment was not effective to raise the productivity of Brachiaria brizantha.
Although the same doses of $\mathrm{N}, \mathrm{K}$ and micronutrients had been applied to the treatments $\mathrm{HE}$ and $\mathrm{HA}$, no increase in productivity was observed compared to the $\mathrm{C}$ treatment, indicating that $\mathrm{P}$ was probably most limiting to productivity increase in the HE treatment, as previously mentioned. Dias Filho (1998) argues that grasses of degraded pastures in the Amazon respond better to $\mathrm{P}$ fertilization than to fertilization with other nutrients, since soils in the Amazon are low in P (McGrath et al., 2001).

Comparing $\mathrm{N}$ fertilization in the most productive treatments, the yield in treatment HA, despite a $25 \%$ higher $\mathrm{N}$ application than in treatment $\mathrm{R}$, was not significantly higher than in the latter. Yields in the treatments HA and R did not differ either from the S treatment, which had not been $\mathrm{N}$-fertilized. This shows that $\mathrm{N}$ fertilization only at the beginning of the experiment induced no yield changes.

The similar yield values found in the treatments $\mathrm{HA}, \mathrm{R}$ and $\mathrm{S}$ show that the application of a $92 \%$ higher $P$ rate than in the treatments $R$ and $S$ did not result in a significantly higher yield in HA than in the latter two. This indicates that, although a lower $\mathrm{P}$ dose was used in no-tillage crops of rice and soybean than in treatment HA, and despite the possible export of this element at harvest, the establishment $B$. brizantha was favored by fertilizer residual effect in the treatments $\mathrm{R}$ and $\mathrm{S}$.

\section{CONCLUSIONS}

1. The effect of calcined phosphate fertilization was observed in the surface soil layer, five months after the beginning of the experiment in the treatments $\mathrm{HA}, \mathrm{S}$ and R. Calcium and magnesium contents increased in the treatments HA and S, and calcium in $R$, although these effects were temporary.

2. Potassium and nitrogen fertilization in the treatments $\mathrm{HE}$ and $\mathrm{R}$, and potassium fertilization in $\mathrm{S}$ did not raise the contents of these nutrients in the soil. In the fifth month of the experiment, the decrease in values of these nutrients in the surfce soil layer in treatments $\mathrm{R}$ and $\mathrm{S}$ was attributed to the ineffectiveness of cycling, due to the harvest of the crops.

3. Phosphate application was effective to increase $\mathrm{P}$ levels in the soil, resulting in the maintenance of exchangeable $\mathrm{P}$ contents considered appropriate for $B$. brizantha in the long term in the P-fertilized treatments, demonstrating the beneficial effect of $\mathrm{P}$ fertilization.

4. Crop - pasture integration in pasture recovery and the use of phosphate fertilizer are effective to increase grass dry matter yield and represent a promising possibility to preserve pasture productivity in the Amazon, which may contribute to the 
sustainability of the livestock activity and the reduction of deforestation in the region. The practice of no-tillage is more recommended for pasture recovery than simple reseeding and fertilization, due to the residual effect of fertilization in no-tillage.

\section{ACKNOWLEDGEMENTS}

We are thankful to FAPESP - Fundação de Amparo Pesquisa do Estado de São Paulo for financial support of this research and we also thank Fazenda Nova Vida - Rondônia for availability of the study area. The first author is indebted to $\mathrm{CNPq}-$ Conselho Nacional de Desenvolvimento Científico e Tecnológico for granting a $\mathrm{PhD}$ scholarship.

\section{LITERATURE CITED}

ALFAIA, S.S.; RIBEIRO, G.A.; NOBRE, A.D.; LUIZÃO, R.C. \& LUIZÃO, F.J. Evaluation of soil fertility in stallholder agroforestry systems and pastures in western Amazon. Agric. Ecosyst. Environ., 102:409-414, 2004.

ARAÚJO, E.A.; LANI, J.L.; AMARAL, E.F. \& GERRA, A. Uso da terra e propriedades físicas e químicas de Argissolo Amarelo distrófico na Amazônia Ocidental. R. Bras.Ci. Solo, 28:307-315, 2004.

ARRUDA, N.G.; CANTARUTTI, R.B. \& MOREIRA, E.M. Tratamentos físicos-mecânicos e fertilização na recuperação de pastagens de Brachiaria decumbens em solos de Tabuleiro. Past. Trop., 9:36-39, 1987.

BASTOS, T.X. \& DINIZ, T.D.A.S. Avaliação do clima do Estado de Rondônia para o desenvolvimento agrícola. Belém, Embrapa-CPATU, 1982. 28p. (Boletim de Pesquisa, 44).

BODDEY, R.M.; RAO, I.M. \& THOMAS, R.J. Nutrient cycling and environmental impact of Brachiaria pasture. In: MILES, J.W.; MAASS, B.L. \& VALLE, C.B. Brachiaria: Biology, agronomy and improvement. Cali, CIAT; Embrapa, CNPGC, 1996. p.53-71.

BOMFIM, E.R.P. Tratamentos físicos associados à adubação na recuperação de pastagem degradada de Braquiária. Lavras, Universidade Federal de Lavras, 2001. 100p. (Tese de Mestrado).

BUSCHBACHER, R.; UHL, C. \& SERRAO, A.S. Abandoned pastures in eastern Amazonia. II. Nutrient stocks in the soil and vegetation. J. Ecol., 76:682-699, 1988.

CAMERON, A.G. Seasonal changes in soil available phosphorus concentrations. Technote, 95:4, 1996. (Abstract in CAB Abstracts n. 19971901261)

CARVALHO, M.C.S. Praticas de recuperação de uma pastagem degradada e seus impactos em atributos físicos, químicos e microbiológicos do solo. Piracicaba, Escola Superior de Agricultura "Luiz de Queiroz", 1999. 103p. (Tese de Doutorado)
CARVALHO, S.I.; VILELA, L; SPAIN, J.M. \& KARIA, C.T. Recuperação de áreas pastagens degradadas de $B$. decumbens cv. Basilik na região dos cerrados. Past. Trop., 12:24-28, 1990.

CERRI, C.E.P.; BERNOUX, M.; CHAPLOT, V.; VOLKOFF, B.; VICTORIA, R.L.; MELILLO, J. M.; PAUSTIAN, K. \& CERRI, C.C. Assessment of soil property spatial variation in an Amazon pasture: Basis for selecting an agronomic experimental area. Geoderma, 123:51-68, 2004.

CERRI, C.E.P.; EASTER, M.; PAUSTIAN, K.; KILLIAN, K.; COLEMAN, K.; BERNOUX, M.; FALLON, P.; POWLSON, D.; MILNE, E. \& CERRI, C.C. Simulating soil organic carbon changes in eleven land use change chronosequences from the Brazilian Amazon with RothC and Century models. Agric. Ecosyst. Environ.,122:46-57, 2007.

COCHRAN, G. C. \& COX, G. M. Diseños experimentales. Mexico, Trillas, 1978. 615p.

CORAZZA, E.J. Biodisponibilidade do íon fosfato em solos sob pastagens cultivadas na Região do Cerrado. Piracicaba, Escola Superior de Agricultura "Luiz de Queiroz", 2002. 127p. (Tese de Doutorado)

CORREA, J.C. \& REICHARDT, K. Efeito do tempo de uso das pastagens sobre as propriedades de um Latossolo Amarelo da Amazônia central. Pesq. Agropec. Bras., 30, 1:107-114, 1995

COSTA, N.L.; THUNG, M.; TOWNSEND, C.R.; MOREIRA, P. \& LEÔNIDAS, F.C. Quantificação das características físicas do solo sob pastagens degradadas. Past. Trop., 21:7477, 1999.

COSTA, N.L.; TOWNSEND, C.R. \& MAGALHÃES, J.A. Métodos de introdução de leguminosas em pastagens degradadas de Brachiaria brizantha cv. Murundu. Past. Trop., 25:39-41, 2003.

DIAS, L.E. \& GRIFFITH, J.J. Conceituação e caracterização de áreas degradadas. In: DIAS, L.E. \& MELLO, J.W.V., eds. Recuperação de áreas degradadas. Viçosa, MG, Universidade Federal de Viçosa, 1998. p.1-7.

DIAS FILHO, M.B. Pastagens cultivadas na Amazônia oriental brasileira: Processos e causas de degradação e estratégias de recuperação. In: DIAS, L.E. \& MELLO, J.W.V., eds. Recuperação de áreas degradadas. Viçosa, MG, Universidade Federal de Viçosa, 1998. p.137-147.

DIAS-FILHO, M.B.; DAVIDSON, E.A. \& CARVALHO, C.J.R. Linking biogeochemical cycles to cattle pasture management and sustainability in the Amazon Basin. In: MCCLAIN M.E.; VICTORIA R.L. \& RICHEY J.E., eds. The biogeochemistry of the Amazon Basin. New York, Oxford University Press, 2001. p.84-105.

EUCLIDES, V.P.B. Alternativas para intensificação da produção de carne bovina em pastagem. Campo Grande, Embrapa Gado de Corte, 2000. 65p.

FEARNSIDE, P.M. Amazonian deforestation and global warming: Carbon stoks in vegetation replacing Brazil's Amazon forest. For. Ecol. Manag., 80:213, 1996.

FEIGL, B.J.; MELILLO, J. \& CERRI, C.C. Changes in the origin and quality of soil organic matter after pasture introduction in Rondonia (Brazil). Plant Soil, 175:21-29, 1995. 
FUJISAKA, S.; BELL, W.; THOMAS, N.; HURTADO, L. \& CRAWFORD, E. Slash-and-burn agriculture, conversion to pasture, and deforestation in two Brazilian Amazon colonies. Agric. Ecosyst. Environ., 59:115-130, 1996.

FUJISAKA, S. \& WHITE, D. Slash-and-burn agriculture, conversion to pasture, and deforestation in two Brazilian Amazon colonies. Agrofor. Syst., 42:45-59, 1998.

GARCIA-MONTIEL, D.C.; NEILL, C.; MELILLO, J.; THOMAS, S.; STEUDLER, P.A. \& CERRI, C.C. Soil phosphorus transformations following forest clearing for pasture in the Brazilian Amazon. Soil Sci. Soc. Am. J., 64:1792-1804, 2000 .

MARTÍNEZ, L.J. \& ZINCK, J.A. Temporal variation of soil compaction and deterioration of soil quality in pasture areas of Colombian Amazonia. Soil Till. Res., 75:3-17, 2004.

McGRATH, D.A.; SMITH, C.K.; GHOLZ, H.L. \& OLIVEIRA, F.A. Effects of land-use changes on soil nutrient dynamics in Amazonia. Ecosystems, 4:625-645, 2001.

MORAES, J.F.L.; VOLKOFF, B.;CERRI, C.C. \& BERNOUX, M. Soil properties under Amazon forest and changes due to pasture installation in Rondonia, Brazil. Geoderma, 70:63-81, 1996 .

NEILL, C.; PICCOLO, M.C.; STEUDLER, P.A.; MELILLO, J.M.; FEIGL, B.J. \& CERRI, C.C. Nitrogen dynamics in soils of forest and active pastures in the western Brazilian Amazon Basin. Soil Biol. Biochem., 27:1167-1175, 1995.

NEILL, C.; MELILLO, J.M.; STEUDLER, P.A.; CERRI, C.; MORAES, F.L.; PICCOLO, F.C. \& BRITO, M. Soil carbon and nitrogen stocks following forest clearing for pasture in the southwestern Brazilian Amazon. Ecol. Appl., 6:12161225, 1997.

NEILL, C.; MELILLO, J.M.; FEIGL, B.J.; STEUDLER, P.A.; MORAES, J.F.L. \& PICCOLO, M.C. Stocks and dynamics of soil carbon following deforestation for pasture in Rondonia. In: LAL, R.; KIMBLE, J.M.; FOLLETT, R.F. \& STEWART, B.A. eds. Boca Raton, CRC Press, 1998. p.928 .
NEILL, C.; PICCOLO, M.C.; MELILLO, J.M.; STEUDLER, P.A. \& CERRI, C.C. Nitrogen dynamics in Amazon forest and pasture soils measured by ${ }^{15} \mathrm{~N}$ pool diluition. Soil Biol. Biochem., 31:567-572, 1999.

PEDREIRA, C.G.S.; PEDREIRA, B.C. \& TONATO, F. Quantificação da massa e produção de forragem em pastagens. In: SIMPÓSIO SOBRE MANEJO DA PASTAGEM, 22., Piracicaba, 2005. Anais... Piracicaba, FEALQ, 2005. p.195-216.

SAS Institute. SAS/STAT guide for personal computers. Version 6. Cary, 1987. 1v.

RAIJ, B.van; ANDRADE, J.C.; CANTARELLA, H. \& QUAGGIO, J.A. Análise química para avaliação da fertilidade de solos tropicais. Campinas, Instituto Agronômico de Campinas, 2001. 284p.

SOARES FILHO, C.V.; MONTEIRO, F.A. \& CORSI, M. Recuperação de pastagens degradadas de Brachiaria decumbens. 1. Efeito de diferentes tratamentos de fertilização e manejo. Past. Trop., 14:2-6, 1992.

SOUSA, D.M.G.; VILELA, L.; LOBATO, E. \& SOARES, W.V. Uso de gesso, calcário e adubos para pastagens no cerrado. Planaltina, Embrapa Cerrados, 2001. 22p. (Circular Técnica, 12)

TORRES J.L.R. \& PEREIRA, M.G. Dinâmica do potássio nos resíduos vegetais de plantas de cobertura no cerrado. $R$. Bras. Ci. Solo, 32:1609-1618, 2008.

URQUIAGA, S.; ALVES, B.J.R. \& BODDEY, R.M. Caracterização de degradação de pastagens e avaliação técnica de recuperação usando-se leguminosas forrageiras. Seropédica, Embrapa, CNPAB, 1998. 21p. (Documentos, 52)

WERNER, J.C.; PAULINO, V.T.; CANTARELLA, H.; ANDRADE, N.O. \& QUAGGIO, J.A. Forrageiras. In: RAIJ, B.van; CANTARELLA, H.; QUAGIO, J.A. \& FURLANI, A.M.C. Recomendações para adubação e calagem para o Estado de São Paulo. 2.ed. Campinas, Instituto Agronômico/Fundação IAC, 1996. p.261-273. 